
Martyna SOBCZYK ${ }^{1}$

\title{
DATT MARKERS LINKED WITH GENES CONTROLLING RESTORATION OF MALE FERTILITY IN HYBRID RYE CULTIVARS WITH IMPROVED POLLEN SHEDDING
}

\section{MARKERY DArT SPRZĘŻONE Z GENAMI KONTROLUJĄCYMI PRZYWRACANIE MĘSKIEJ PŁODNOŚCI W ODMIANACH MIESZAŃCOWYCH ŻYTA O POPRAWIONEJ ZDOLNOŚCI PYLENIA}

\author{
1Department of Plant Genetics, Breeding and Biotechnology, West Pomeranian University \\ of Technology, Szczecin, Poland \\ 2DANKO Plant Breeding Ltd., Choryń, Poland
}

\begin{abstract}
Streszczenie. Celem pracy było użycie wysokoprzepustowej technologii genotypowania do zlokalizowania genów odpowiedzialnych za przywracanie męskiej płodności w odmianie mieszańcowej żyta zawierającej sterylizującą cytoplazmę Pampa. Metodę Diversity Arrays Technology (DArT) zastosowano do analiz w obrębie 48 osobników populacji F2 otrzymanej w wyniku krzyżowania pomiędzy męskosterylną linią S305P a losowo wybraną rośliną odmiany Gonello F1. Analizy DArT były uzupełnione dostępnymi w literaturze markerami opartymi na metodzie PCR, związanymi z przywracaniem płodności w CMS-Pampa lub alternatywnymi źródłami CMS żyta. Ogółem do genotypowania użyto ponad 3300 markerów. Skonstruowana mapa genetyczna obejmowała siedem grup sprzężeń zawierających łącznie 763 markery i pokrywała obszar ok. $520 \mathrm{cM}$. Osiemdziesiąt markerów molekularnych wykazywało statystycznie istotny związek z przywracaniem płodności w badanej populacji. Ich rozmieszczenie wskazuje na dwa regiony genomu istotne dla przywracania płodności - chromosom 4RL z silnym genem restorerowym oraz $1 \mathrm{R}$ z genem o mniejszym efekcie fenotypowym. Lokalizacje te okazały się zgodne z wcześniejszymi danymi literaturowymi. Nowe markery molekularne z tych obszarów, istotnie związane z przywracaniem płodności, zostały zidentyfikowane. Między nimi znajdują się markery oparte na PCR, ale otrzymane w wyniku konwersji z markerów DArT.
\end{abstract}

Key words: cytoplasmic male sterility, hybrid cultivars, restorer genes, rye.

Słowa kluczowe: cytoplazmatyczna męska sterylność, geny przywracania płodności, odmiany mieszańcowe, żyto.

\section{INTRODUCTION}

Rye hybrid cultivars have been grown in Europe for more than 30 years. Almost all those cultivars are produced based on the cytoplasmic male sterility Pampa system (CMS-Pampa) discovered by Geiger and Schnell (1970) in the population of Argentinian rye. In European

Corresponding author - Autor do korespondencji: Stefan Stojałowski, Department of Plant Genetics, Breeding and Biotechnology, West Pomeranian University of Technology, Szczecin, Poland, e-mail: sstojalowski@zut.edu.pl 
rye populations, a majority of genotypes maintain male sterility in hybrids with the Pampa cytoplasm, however they lack efficient restorer genes (Geiger and Miedaner 1996). A genetic mechanism of the male fertility restoration in CMS-P in European rye resources is complex and depends on the activity of several loci located on chromosomes $1 R, 3 R, 4 R, 5 R$, and $6 R$ (Miedaner et al. 2000). However, it was found that the highly effective restorer gene from the primitive Iranian rye population (Geiger and Miedaner 1996) localized in the Rfp1 locus on the long arm of the $4 R$ chromosome (Miedaner et al. 2000) can effectively supplement the male fertility restoration in the CMS-P rye hybrid. The development of PCR-based sequence characterized amplified region (SCAR) molecular markers tightly linked with the Rfp1 gene (Stracke et al. 2003) allowed a relatively fast and precise transfer of this gene from the primitive IRAN IX rye population to advanced European breeding lines through the markerassisted backcrossing (MAB) method. Consequently, in the last decade, hybrid cultivars based on the CMS-P system with significantly increased pollen shedding efficiency were successfully registered in Germany, Poland, and other countries. The breeding company KWS (Einbeck, Germany) developed and subsequently introduced cultivars containing the $R f p 1$ gene under the PollenPlus ${ }^{\circledR}$ trademark (Żyto ozime, http://www.kws-zboza.pl/en/ /odmiany/wszystkie-odmiany/zboze/zyto-ozime.html). The main advantage of PollenPlus ${ }^{\circledR}$ cultivars is their significantly reduced sensitivity to the ergot (Claviceps purpurea) infection as compared to other rye hybrids containing the CMS-P system.

Recently, several high-throughput genotyping methods significantly accelerating genetic analyses of numerous crops were developed. Among them, the diversity arrays technology (DArT) was successfully applied in rye research (Bolibok-Brągoszewska et al. 2009; Milczarski et al. 2011; Stojałowski et al. 2011, 2015; Myśków et al. 2014; Gawroński et al. 2016; Myśków and Stojałowski 2016). Therefore, in this study we applied the DArT technology to verify the Rfp 1 gene efficacy in restoration of male fertility in PollenPlus $₫$ cultivars. We were interested whether the high level of pollen shedding results only from the presence of $R f p 1$ or other minor restorer genes are also required to restore male fertility in these cultivars.

\section{MATERIAL AND METHODS}

Twenty-seven individual plants originating from two PollenPlus ${ }^{\circledR}$ cultivars (Visello F1 and Gonello F1) registered by KWS (Einbeck, Germany) were phenotyped in 2010 in a glasshouse of the West Pomeranian University of Technology in Szczecin. The assessment of male fertility/sterility was performed by visual observations using a bonitation scale developed by Geiger and Morgenstern (1975). To verify data obtained from a visual assessment, the main ear of each plant was bagged before flowering, and after harvesting, the seed setting was analyzed additionally. During flowering, pollen collected from non-isolated ears of the one randomly chosen individual showing high male fertility (Gonello 249-1) was used for crosses with a male sterile inbred line.

As a maternal component of the mapping population, the male-sterile inbred line S305P provided by Danko Plant Breeding Ltd. (Choryń, Poland) was used.

Subsequently, a fully male fertile F1 plant was selfed in order to develop the F2 mapping population. This population was phenotyped in two vegetation seasons (2012 and 2015) under field conditions on plots of an experimental station of the West Pomeranian University 
of Technology, Szczecin. Individuals were planted separately in $25 \mathrm{~cm} \times 25 \mathrm{~cm}$ intervals. In total, 289 individuals were phenotyped. The male fertility of plants was assessed visually according to the Geiger and Morgenstern (1975). Results were verified by analyzing the seed setting under bags. In 2012, the main ear of each plant was isolated before flowering, whereas in 2015 three ears were bagged. The consistency of these two methods used for the evaluation of male sterility/fertility was estimated by calculating the correlation coefficients.

DNA of each individual of the mapping population was extracted from leaves collected at the beginning of the shooting phase. In total, 48 individuals revealing strong sterility and high male fertility (assessment confirmed by both methods of phenotyping) were selected for genotyping. DNA from selected F2 plants and parental lines was isolated using the Gene Elute Plant DNA Mini Kit (Sigma-Aldrich). Genotyping was performed using DArT provided as a service by DArT P/L (Australia) - Diversity Arrays Technology, http://www.diversityarrays.com. The high-throughput DArT genotyping was complemented by PCR-based markers from the 4RL chromosome reported in Stojałowski et al. (2011), Hackauf et al. (2012), and Milczarski et al. (2016). Seven PCR markers (Table 1) were developed on the bases of DArT sequences (Gawroński et al. 2016). During the conversion of DArT markers into PCR-based SCARs, the original marker prefix "XrPt" was replaced by "d," whereas the related clone ID remained unchanged.

Table 1. Primer sequences of PCR markers developed on the basis of DNA sequences of DArT clones Tabela 1. Sekwencje starterów dla markerów PCR wytworzonych na podstawie sekwencji DNA klonów DArT

\begin{tabular}{lll}
\hline $\begin{array}{c}\text { Clone ID } \\
\text { Numer klonu }\end{array}$ & \multicolumn{1}{c}{$\begin{array}{c}\text { Forward sequence } \\
\text { Starter } \mathrm{F}\end{array}$} & \multicolumn{1}{c}{$\begin{array}{c}\text { Reverse sequence } \\
\text { Starter R }\end{array}$} \\
\hline 390763 & CCATCTGCTAGGTCAGGCG & ATGTACGATGGTTCACCACC \\
\hline 398695 & GCAGCTTCCAGATTAGCCAT & TGAATTCCTTTATTATAGCCTCCA \\
\hline $400382^{*}$ & GGTGCGCGGTCATCAGAAA & CGGTGTGGACACACACATC \\
\hline 505904 & AGAAAGTCATTGTCGGGGAA & AGAAGTTAAAAACGTATTGCAAAT \\
\hline 508318 & AGGGTCAAGCATGAAGACCTCT & CTTACATGCGACGGTCGTGA \\
\hline $508573^{*}$ & GCAGCTTTAACACCAACACCT & GGCCGTGCATGGTAGACAT \\
\hline $508800^{*}$ & GCGGTCATCAGAAAGGCTAGT & TGCAACTTTACCAGCGAAGG \\
\hline
\end{tabular}

* Reported by Milczarski et al. (2016) - Opisane w pracy Milczarski i in. (2016).

In order to identify a relationship between molecular markers and results of male fertility phenotyping, the Kruskal-Wallis (K-W) rank test was applied. Markers were considered to be significantly associated with the studied trait if $p<0.001$. Data obtained from the molecular marker segregation analysis were used to construct the genetic map using the JoinMap 3.0 software (Van Ooijen and Voorrips 2001). Linkage groups were constructed at LOD $=4$. Only two rounds of the mapping procedure were performed (the third round, optional in the software, was excluded.) Developed linkage maps were compared with the consensus genetic map of rye based on DArT markers (Milczarski et al. 2011) to assign them to particular chromosomes. Finally, the interval mapping (IM) procedure was performed using the MapQTL 5.0 package (Van Ooijen 2004). The putative localization of the gene/genes controlling male fertility restoration was considered when the LOD value exceeded 3.0. An additional threshold of significance for declaring the presence of the quantitative trait locus (QTL) was estimated by using a permutation test (at 1000 permutations). 


\section{RESULTS}

A small sample size of both randomly chosen genotypes originating from two PollenPlus ${ }^{\circledR}$ cultivars were assessed for male fertility: 17 individuals of Visello F1 and 10 of Gonello F1. Although, high pollen shedding was observed in majority of examined plants, fully sterile individuals were also found in both hybrid varieties (Table 2).

Table 2. Number of plants classified as male sterile (MS) and male fertile (MF) within cultivars Visello F1 and Gonello F1 in glasshouse 2010

Tabela 2. Liczebność roślin ocenionych jako męskosterylne (MS) i męskopłodne (MP) w obrębie odmian Visello F1 i Gonello F1 rosnących w szklarni w 2010 r.

\begin{tabular}{lccc}
\hline \multicolumn{1}{c}{ Cultivar - Odmiana } & MS & MP & Total - Razem \\
\hline Visello F1 & 4 & 13 & 17 \\
\hline Gonello F1 & 1 & 9 & 10 \\
\hline
\end{tabular}

The assessment of male sterility/fertility in the F2 mapping population of the cross [S305P $\times$ Gonello 249-1] revealed a bi-modal distribution of phenotypes (Table 3). Irrespectively of the year of the study, the most frequent phenotypes belonged to two classes: fully male sterile plants (classified in the Geiger and Morgenstern scale as 1-2) and fully male fertile ones (8-9 in the bonitation scale). Plants with partially restored male fertility were also present, however at a low number. Results of the visual observation of pollen shedding were highly consistent with those from the seed setting analysis-correlation coefficients in both years of the study (2012 and 2015) were estimated to be 0.88-0.89 (Table 3).

For genotyping, the set of 48 individuals was selected: 23 male sterile and 25 male fertile plants. Partly fertile individuals were not subjected to genotyping due to their uncertain assessment of the sterility/fertility class. For genotyping, individuals with fully consistent results of the visual assessment and seed setting were favored. Moreover, the correlation coefficient between both phenotyping methods was calculated to be 0.99 for selected groups (Table 3). The distribution of phenotypes studied in both years of study was significantly correlated. On the other hand, the calculated value of correlation coefficient: $R=0.48$, indicates that the impact of environment on male fertility shouldn't be skipped.

The DArT analysis provided the data for 3359 DArT markers. Among them, 1541 revealed polymorphism within the studied material (hybrid of the inbred line S305P and individual plant of the Gonello F1 cv.). These data were supported by results of the PCR analyses performed using previously mapped markers form the 4RL chromosome: two SCARs (Stojałowski et al. 2011), 25 conserved ortholog set (COS) (Hackauf et al. 2012), and 7 PCR markers developed from DArT sequences (Table 4). The application of the $\mathrm{K}-\mathrm{W}$ test revealed 80 molecular markers significantly (at $p<0.001$ ) associated with the male fertility restoration in studied plants. Among them, 75 were DArT markers, whereas remaining 5 were obtained by the PCR method (Table 4). Only one molecular marker, the COS marker TC 237550 developed by Hackauf et al. (2012) listed in the Table 4, revealed a co-dominant character. For 23 markers, the maternal allele was recorded in fully male-sterile plants. In contrast, the frequency of developed grains in the spikes of genotypes carrying the paternal allele of the markers exceeded $60 \%$ in all studied cases (Table 4 ). 
Table 3. Phenotypic classification of the studied F2 population developed from the cross S305P x Gonello 249-1

Tabela 3. Wyniki fenotypowej oceny roślin populacji F2 otrzymanej z mieszańca S305P x Gonello 249-1

\begin{tabular}{|c|c|c|c|c|c|c|c|c|c|c|c|}
\hline \multirow{2}{*}{$\begin{array}{l}\text { Population / subpopulation } \\
\text { Populacja / część populacji }\end{array}$} & \multicolumn{9}{|c|}{$\begin{array}{l}\text { Classification in bonitation scale by Geiger and Morgenstern (1975) } \\
\text { Klasyfikacja wg skali bonitacyjnej Geigera i Morgensterna (1975) }\end{array}$} & \multirow{2}{*}{$\begin{array}{l}\text { Total } \\
\text { Ogółem }\end{array}$} & \multirow{2}{*}{$\begin{array}{l}\text { Correlator } \\
\text { Korelacja }\end{array}$} \\
\hline & 1 & 2 & 3 & 4 & 5 & 6 & 7 & 8 & 9 & & \\
\hline $\begin{array}{l}\text { Phenotyped in } 2012 \\
\text { Oceniona w } 2012\end{array}$ & 25 & 5 & 3 & 1 & 4 & 2 & 7 & 94 & 62 & 203 & 0.89 \\
\hline $\begin{array}{l}\text { Phenotyped in } 2015 \\
\text { Oceniona w } 2015\end{array}$ & 14 & 6 & 2 & 2 & 3 & 2 & 1 & 4 & 52 & 86 & 0.88 \\
\hline $\begin{array}{l}\text { Total } \\
\text { Ogółem }\end{array}$ & 39 & 11 & 5 & 3 & 7 & 4 & 8 & 98 & 114 & 289 & \\
\hline $\begin{array}{l}\text { Selected for DArT analysis } \\
\text { Wybrana do analiz DArT }\end{array}$ & 20 & 3 & 0 & 0 & 0 & 0 & 0 & 14 & 11 & 48 & 0.99 \\
\hline
\end{tabular}

${ }^{*}$ Correlation coefficient between visual assessment of male fertility (using the scale suggested by Geiger and Morgenstern) and results of seed setting under bags -

Współczynnik korelacji pomiędzy wynikami oceny wzrokowej pylenia (wykonanej wg skali Geigera i Morgensterna) a rezultatami oceny zawiązywania ziaren pod izolatorami. 
Table 4. Molecular markers revealing in the Kruskal-Wallis $(\mathrm{K}-\mathrm{W})$ test significant association with seed setting in isolated spikes

Tabela 4. Markery molekularne wykazujące $\mathrm{w}$ teście Kruskala-Wallisa $(\mathrm{K}-\mathrm{W})$ istotny związek z wartościami zawiązywania ziaren pod izolatorami

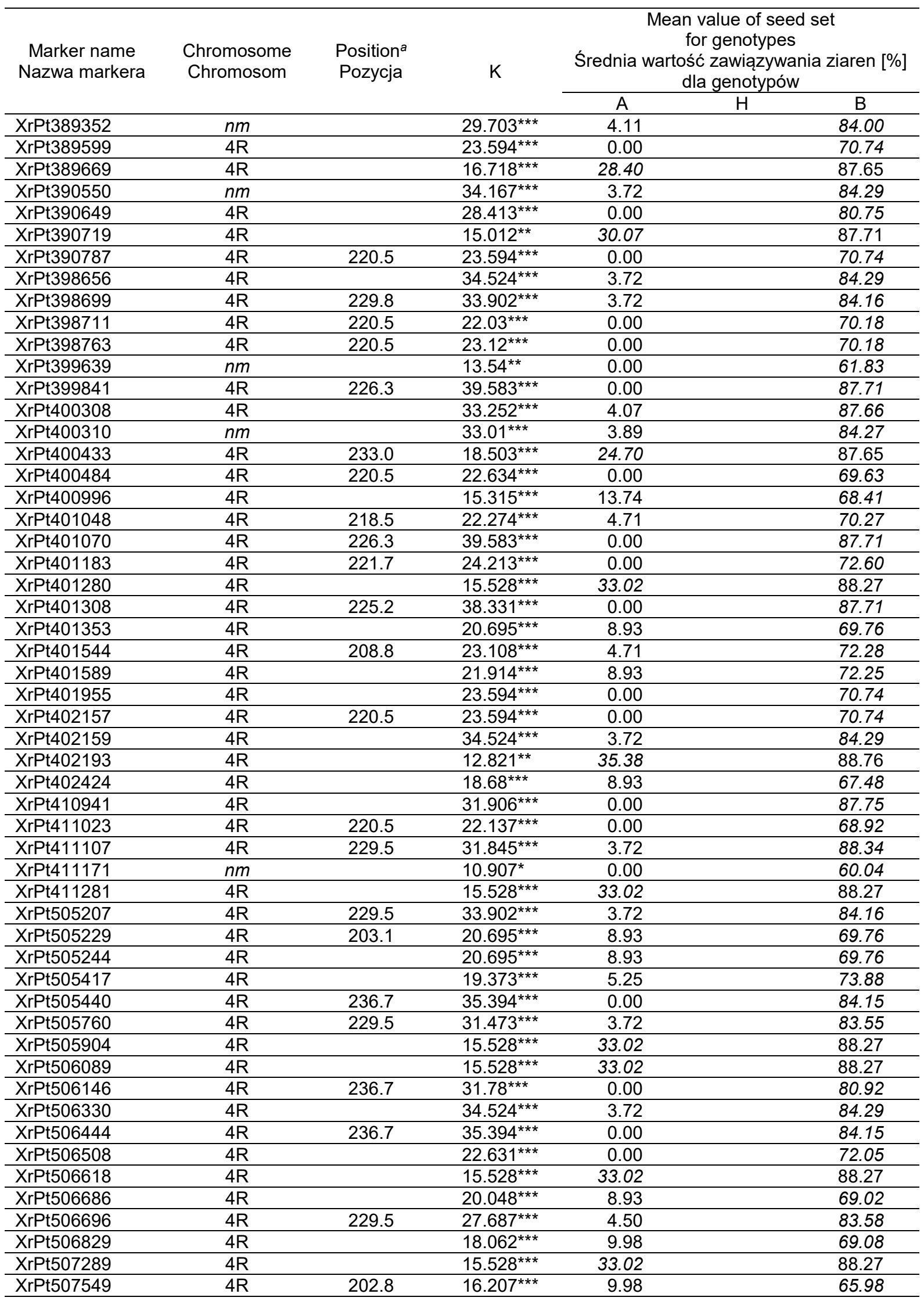


Table 4. Molecular markers revealing in the Kruskal-Wallis $(\mathrm{K}-\mathrm{W})$ test significant association with seed setting in isolated spikes (cont.)

Tabela 4. Markery molekularne wykazujące $w$ teście Kruskala-Wallisa $(K-W)$ istotny związek z wartościami zawiązywania ziaren pod izolatorami (cd.)

\begin{tabular}{|c|c|c|c|c|c|c|}
\hline \multirow[t]{2}{*}{$\begin{array}{l}\text { Marker name } \\
\text { Nazwa markera }\end{array}$} & \multirow[t]{2}{*}{$\begin{array}{l}\text { Chromosome } \\
\text { Chromosom }\end{array}$} & \multirow[t]{2}{*}{$\begin{array}{l}\text { Position }^{a} \\
\text { Pozycja }\end{array}$} & \multirow[t]{2}{*}{$\mathrm{K}$} & \multicolumn{3}{|c|}{$\begin{array}{c}\text { Mean value of seed set } \\
\text { for genotypes } \\
\text { Średnia wartość zawiązywania ziaren [\%] } \\
\text { dla genotypów }\end{array}$} \\
\hline & & & & A & $\mathrm{H}$ & $\mathrm{B}$ \\
\hline XrPt507555 & $4 \mathrm{R}$ & & $15.447^{* * *}$ & 26.35 & & 87.42 \\
\hline XrPt507880 & $4 \mathrm{R}$ & & $18.205^{\star * *}$ & 25.43 & & 87.65 \\
\hline XrPt508260 & $4 \mathrm{R}$ & & $21.062^{* * *}$ & 0.00 & & 67.99 \\
\hline XrPt508459 & $4 \mathrm{R}$ & 202.8 & $18.375^{\star * *}$ & 9.98 & & 69.23 \\
\hline XrPt508466 & $4 \mathrm{R}$ & 202.8 & $20.695^{\star \star *}$ & 8.93 & & 69.76 \\
\hline XrPt508542 & $n m$ & & $11.501^{*}$ & 31.02 & & 81.30 \\
\hline XrPt508638 & $4 \mathrm{R}$ & 236.7 & $32.877^{* * *}$ & 3.72 & & 83.58 \\
\hline XrPt508693 & $4 \mathrm{R}$ & 207.6 & $22.274^{* * *}$ & 4.71 & & 70.27 \\
\hline XrPt509165 & $4 \mathrm{R}$ & 240.4 & $25.859^{\star * *}$ & 4.28 & & 74.93 \\
\hline XrPt509188 & $4 \mathrm{R}$ & & $20.695^{\star * *}$ & 8.93 & & 69.76 \\
\hline XrPt509241 & 1R & 124.9 & $10.908^{*}$ & 7.23 & & 61.25 \\
\hline XrPt509243 & $4 \mathrm{R}$ & 203.1 & $20.695^{\star * *}$ & 8.93 & & 69.76 \\
\hline XrPt509261 & $4 \mathrm{R}$ & 225.5 & $18.411^{* * *}$ & 26.42 & & 88.27 \\
\hline XrPt509353 & $4 \mathrm{R}$ & 202.8 & $20.695^{\star * *}$ & 8.93 & & 69.76 \\
\hline XrPt509448 & $4 \mathrm{R}$ & 202.8 & $20.695^{\star * *}$ & 8.93 & & 69.76 \\
\hline XrPt509637 & $4 \mathrm{R}$ & 220.5 & $20.024^{* * *}$ & 0.00 & & 68.87 \\
\hline XrPt6659 & $4 \mathrm{R}$ & & $15.502^{* * *}$ & 28.40 & & 87.38 \\
\hline XtPt6710 & $4 \mathrm{R}$ & & $19.475^{\star * *}$ & 22.70 & & 87.65 \\
\hline XwPt4062 & $4 \mathrm{R}$ & & $20.202^{\star * *}$ & 5.37 & & 76.74 \\
\hline XwPt6555 & $n m$ & & $24.363^{* * *}$ & 13.72 & & 87.82 \\
\hline XwPt7498 & $4 \mathrm{R}$ & & $11.323^{*}$ & 15.48 & & 63.64 \\
\hline d390763 & $n m$ & & $31.549^{* * *}$ & 3.89 & & 81.05 \\
\hline d505904 & $4 \mathrm{R}$ & & $15.528^{\star * *}$ & 33.02 & & 88.27 \\
\hline d508318 & $4 \mathrm{R}$ & & $39.583^{* * *}$ & 0.00 & & 87.71 \\
\hline TC237550 & $4 \mathrm{R}$ & & $26.771^{* * *}$ & 4.28 & 69.22 & 81.30 \\
\hline Xscsz23L500 & $4 \mathrm{R}$ & & $23.705^{\star * *}$ & 22.48 & & 88.00 \\
\hline
\end{tabular}

${ }^{a}$ Cumulated position in $\mathrm{CM}$ of the marker on the consensus genetic map of RIL-S population by Milczarski et al. (2011) (no value - the marker was not located on the consensus map of RIL-S population) - Pozycja w cM na mapie konsensusowej dla populacji RIL-S wg Milczarskiego i in. (2011) (brak wartości - marker nie był zlokalizowany na mapie konsensusowej RIL-S).

$\mathrm{K}$ - value of $\mathrm{K}$ statistic $\left(\mathrm{K}-\mathrm{W}\right.$ test) - wartość statystyki $\mathrm{K}$ (test $\mathrm{K}-\mathrm{W}$ ); ${ }^{*}$ significant at $\mathrm{P}<0.001$ - wartości istotne statystycznie przy $\mathrm{P}<0,001$; ${ }^{* *}$ significant at $\mathrm{P}<0.0005-$ istotne przy $\mathrm{P}<0,0005$; ${ }^{* *}$ significant at $P<0.0001$ - istotne przy $P<0,0001$.

Genotypes - Genotypy: A - maternal allele of the marker - allel pochodzący od formy matecznej mieszańca; $\mathrm{B}$ - paternal allele of the marker - allel pochodzenia ojcowskiego; $\mathrm{H}$ - heterozygote - heterozygota.

For dominant markers, where heterozygotes are not distinguishable from homozygotes of one parental form, values are printed in italics - Dla markerów dominujących, które nie pozwalają na odróżnienie heterozygot od homozygot jednej z form rodzicielskich, wartości średnie wyróżniono kursywą.

$\mathrm{nm}-$ not mapped on the genetic maps of RIL-S and [S305P $\times$ Gonello 249-1]F2 population (see Fig.1) niezlokalizowane na mapach populacji RIL-S oraz populacji [S305P $\times$ Gonello 249-1] $F_{2}$ (por. ryc. 1).

The linkage grouping performed in JoinMap 3.0 resulted in the construction of seven groups containing in total 994 markers (Table 5). These groups were assigned to respective chromosomes based on markers previously located on existing genetic maps of rye. Each linkage group consisted of 100-200 loci. Performed mapping analysis allowed localization of 763 markers on maps of linkage groups (Fig. 1, Table 5). Consequently, we obtained the genetic map of high density; an average distance between markers was estimated to be less than $0.7 \mathrm{cM}$. The total length of all 7 linkage maps was approximately $520 \mathrm{cM}$. 

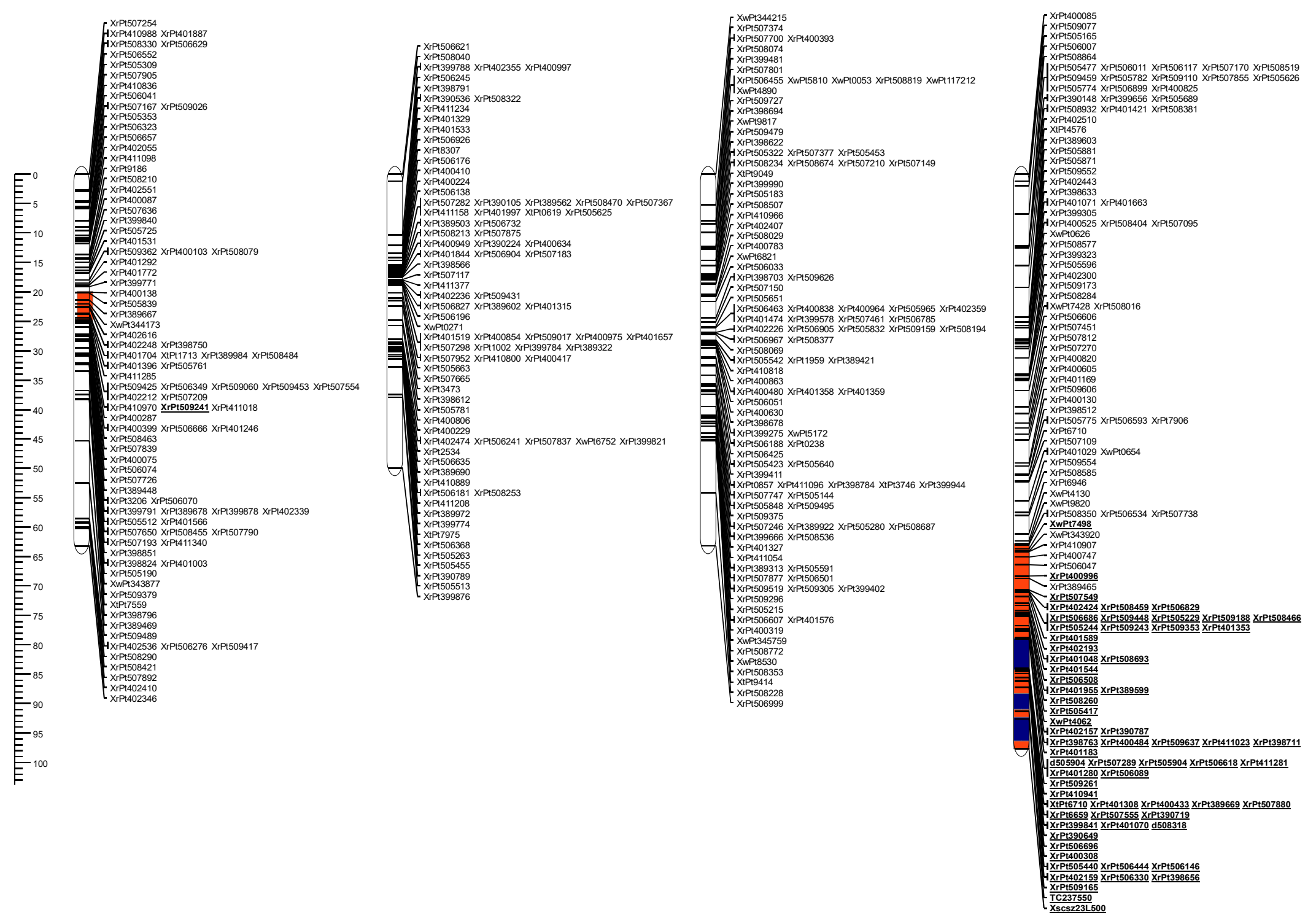

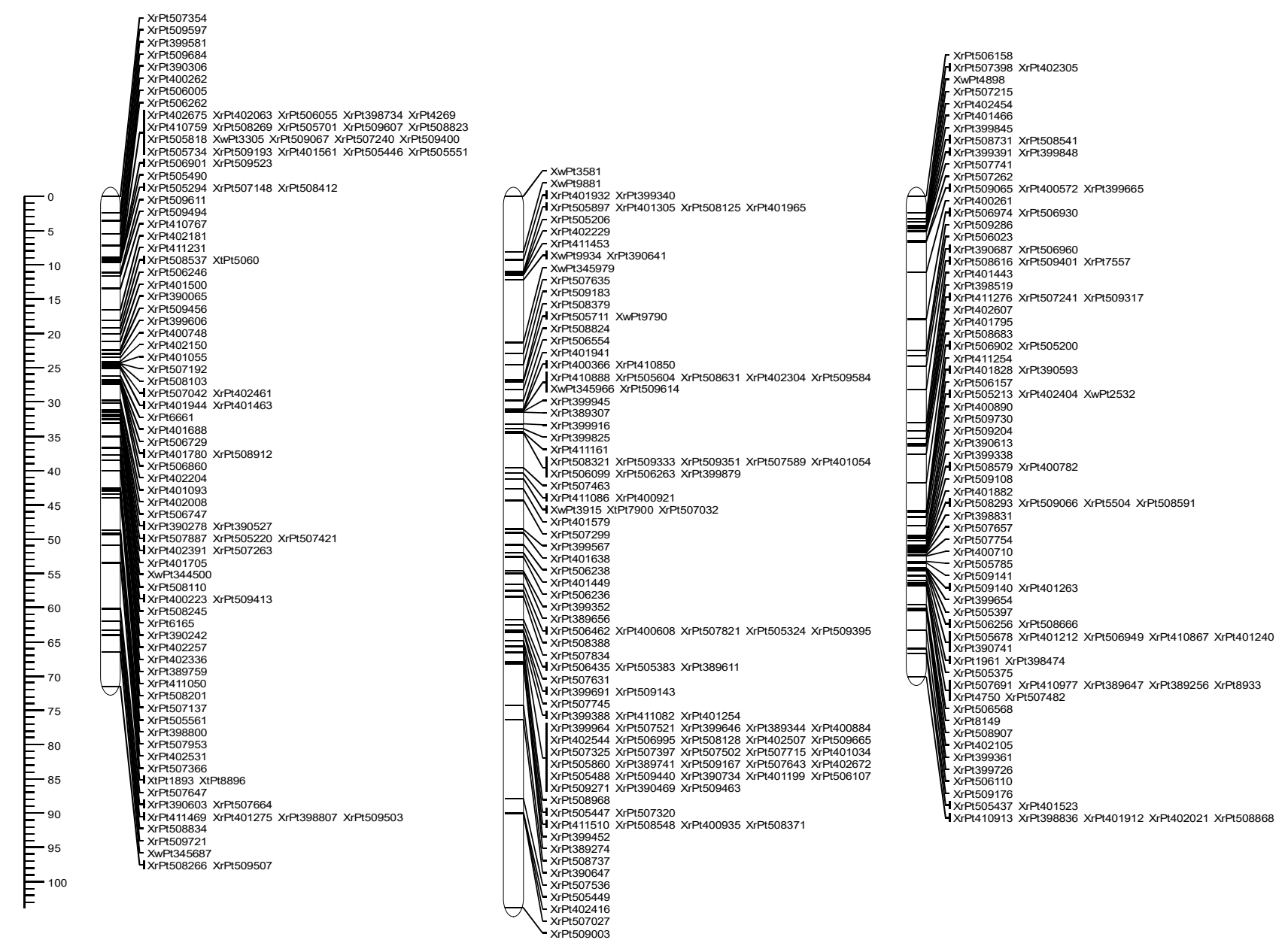

intervals where $L O D>3.0$ - przedzialy z wartościami LOD 3.0

D intervals where LOD significant in Permutation test - przedzialy z wartościami $L O D$ istotnymi $\mathrm{w}$ teście permutacji

Fig. 1. Genetic map of rye chromosomes and localization of genomic regions determining male fertility restoration in the [S305P $\times$ Gonello $249-1] \mathrm{F}_{2}$ population. Markers underlined and printed in bold style were significant in the Kruskal-Wallis test $P<0.001$ )

Ryc. 1. Mapa genetyczna chromosomów żyta i lokalizacja regionów genomu kontrolujących przywracanie męskiej płodności u mieszańca [S305P $\times$ Gonello 249-1] $F_{2}$. Markery, których nazwy zostały podkreślone i wyróżnione pogrubioną czcionką wykazywały statystyczną istotność w teście Kruskala-Wallisa $(P<0,001)$ 
Table 5. Linkage groups (LG) of the [S305P $\times$ Gonello 249-1] $\mathrm{F}_{2}$ mapping population Tabela 5. Grupy sprzężeń (LG) w populacji mapującej [S305P x Gonello 249-1] $F_{2}$

\begin{tabular}{|c|c|c|c|c|}
\hline $\begin{array}{l}\text { Chromosome } \\
\text { Chromosom }\end{array}$ & $\begin{array}{c}\text { Total number of } \\
\text { markers within the LG } \\
\text { Ogólna liczba } \\
\text { markerów w LG }\end{array}$ & $\begin{array}{l}\text { Number of markers } \\
\text { included into map } \\
\text { Liczba markerów } \\
\text { wprowadzonych } \\
\text { na mapę }\end{array}$ & $\begin{array}{c}\text { Total length } \\
\text { Całkowita długość } \\
\text { LG [cM] }\end{array}$ & $\begin{array}{c}\text { Average map } \\
\text { densitya } \\
\text { Średnia gęstość } \\
\text { mapy }\end{array}$ \\
\hline $1 \mathrm{R}$ & 141 & 96 & 63.3 & 0.66 \\
\hline $2 \mathrm{R}$ & 115 & 87 & 50.0 & 0.57 \\
\hline $3 R$ & 148 & 112 & 63.2 & 0.56 \\
\hline $4 \mathrm{R}$ & 200 & 143 & 97.7 & 0.68 \\
\hline $5 \mathrm{R}$ & 113 & 105 & 71.5 & 0.68 \\
\hline $6 \mathrm{R}$ & 150 & 120 & 103.8 & 0.86 \\
\hline $7 \mathrm{R}$ & 127 & 100 & 70.1 & 0.70 \\
\hline $\begin{array}{l}\text { Total } \\
\text { Ogółem (1-7R) }\end{array}$ & 994 & 763 & 519.6 & 0.68 \\
\hline
\end{tabular}

$\mathrm{cM}$ - centiMorgan - centyMorgan.

a Length of LG in cM per number of markers - Długość grupy sprzężeń (w cM) podzielona przez liczbę markerów.

The IM analysis performed to detect QTLs controlling the restoration of male fertility indicated importance of two genomic regions. First, a strong phenotypic effect was associated with the long arm of the chromosome 4R, whereas a moderate effect with the chromosome 1R (Fig. 1). The significance of the QTL detected on chromosome 4RL was confirmed by the permutation test. In both regions, markers indicated by the IM method and showing significance in the $\mathrm{K}-\mathrm{W}$ test were mapped (Fig. 1).

\section{DISCUSSION}

Attempts to identify genes controlling the male fertility restoration in the cytoplasmic male sterility Pampa system were initiated relatively long time ago. In the first study performed by Wricke et al (1993), the restorer gene was localized on the chromosome 1R. Further, Miedaner et al (2000) analyzing three mapping population observed significant differences in the genetic control of male fertility restoration between European and exotic rye populations. In the European inbred line, the most efficient male fertility restorers were found on $1 R S$ and $3 R L$ chromosomes, whereas significantly stronger phenotypic effects were induced by genes from Iranian and South American populations. These genes (or possibly, only one gene present in different resources) were located on the chromosome 4RL. Subsequently, for the effective restorer gene (Rfp1) originating from the IRAN IX population, the set of PCR-based markers was developed (Stracke et al. 2003; Hackauf et al. 2012). This gene was introduced into advanced breeding materials through the MAB method, and subsequently allowed the development and registration of the PollenPlus ${ }^{\circledR}$ cultivars. In the light of these results, the association of the strongest phenotypic effect with the $4 \mathrm{RL}$ chromosome in the mapping population developed using the PollenPlus $®$ cultivar had to be expected. This result confirmed the importance of the Rfp1 gene for the efficient pollen shedding in this cultivar. However, the low number of tested individuals used for genotyping did not allow the construction of the precise map. Considering this limitation, we decided to generate maps performing only two out of three rounds of mapping using JoinMap (Van Ooijen and Voorrips 2001). Markers included in the maps constructed during the first two rounds were located at a higher 
significance. Further, this study resulted in the identification of the new set of DArT markers tightly linked with the Rfp1 gene. Three out of them converted into PCR-based markers, d390763, d505904, and d508318, can be applied to the breeding practice. Moreover, based on the suggestion that DArT makers are effective in targeting the gene space in rye genome (Gawroński et al. 2016 reported here frame maps can be further use for the development of more precise high-resolution maps, and subsequent cloning of the Rfp1 gene.

The identification of the moderate restorer gene on the $1 \mathrm{R}$ chromosome raised an interesting new question whether this gene can also play a significant role in the high pollen production in the Gonello F1 cultivar. The efficiency of Rfp1 seems to be very high, however our knowledge of the genomic control of the male fertility restoration in modern rye hybrid cultivars with the Pampa cytoplasm is still limited. Therefore, it remains difficult to predict whether in the studied cultivar additional restorer genes with moderate efficiency are necessary for pollen production and what their importance is.

\section{RECAPITULATION}

As stated earlier, the presence of the efficient Rfp1 gene from the chromosome $4 R L$, that restores male fertility in hybrid cultivars with the Pampa cytoplasm was confirmed. A set of DArT markers linked with this gene was identified for the first time. Three practically useful PCR-based makers obtained by conversion of DArT markers were reported. Moreover, the presence of the additional moderate restorer gene on the chromosome $1 \mathrm{R}$ was observed in the studied Gonello F1 cultivar.

\section{REFERENCES}

Bolibok-Brągoszewska H., Heller-Uszyńska K., Wenzl P., Uszyński G., Kilian A., Rakoczy-Trojanowska M. 2009. DArT markers for the rye genome - genetic diversity and mapping. BMC Genom. 10, 578.

Diversity Arrays Technology, http://www.diversityarrays.com, access: 31.03.2017.

Gawroński P., Pawełkowicz M., Tofil K., Uszyński G., Sharifova S., Ahluwalia S., Tyrka M., Wędzony M., Kilian A., Bolibok-Brągoszewska H. 2016. DArT markers effectively target gene space in the rye genome. Front. Plant Sci. 7, 1600. DOI: 10.3389/fpls.2016.01600.

Geiger H.H., Miedaner T. 1996. Genetic basis and phenotypic stability of male-fertility restoration in rye. Vortr Pflanzenzüchtg 35, 27-38.

Geiger H.H., Morgenstern K. 1975. Angewandt-genetische Studien zur cytoplasmatischen Pollensterilität bei Winterroggen. Theor. Appl. Genet. 46, 269-276.

Geiger H.H., Schnell F.W. 1970. Cytoplasmatic male sterility in rye (Secale cereale L.). Crop. Sci. 10, 590-593.

Hackauf B., Korzun V., Wortmann H., Wilde P., Wehling P. 2012. Development of conserved ortholog set markers linked to the restorer gene Rfp1 in rye. Mol Breeding 30, 1507-1518.

Miedaner T., Glass C., Dreyer F., Wilde P., Wortmann H., Geiger H.H. 2000. Mapping of genes for male-fertility restoration in 'Pampa' CMS winter rye (Secale cereale L.). Theor. Appl. Genet. 101, 1226-1233.

Milczarski P., Bolibok-Brągoszewska H., Myśków B., Stojałowski S., Heller-Uszyńska K., Góralska M., Brągoszewski P., Uszyński G., Kilian A., Rakoczy-Trojanowska M. 2011. A high density consensus map of rye (Secale cereale L.) based on DArT markers. PLoS ONE 6(12), e28495. DOI:10.1371/ /journal.pone.0028495. 
Milczarski P., Hanek M., Tyrka M., Stojałowski S. 2016. The application of GBS markers for extending the dense genetic map of rye (Secale cereale L.) and the localization of the $R f c 1$ gene restoring male fertility in plants with the $C$ source of sterility-inducing cytoplasm. J. Appl. Genet. 57, 439-451.

Myśków B., Hanek M., Banek-Tabor A., Maciorowski R., Stojałowski S. 2014. The application of high-density genetic maps of rye for the detection of QTLs controlling morphological traits. J. Appl. Genet. 55, 15-26.

Myśków B., Stojałowski S. 2016. Bidirectional selective genotyping approach for the identification of quantitative trait loci controlling earliness per se in winter rye (Secale cereale L.). J. Appl. Genet. 57, $45-50$.

Stojałowski S.A., Milczarski P., Hanek M., Bolibok-Brągoszewska H., Myśków B., Kilian A., Rakoczy-Trojanowska M. 2011. DArT markers tightly linked with the Rfc1 gene controlling restoration of male fertility in the CMS-C system in cultivated rye (Secale cereale L.). J. Appl. Genet. 52, 313-318.

Stojałowski S., Myśków B., Hanek M. 2015. Phenotypic effect and chromosomal localization of Ddw3, the dominant dwarfing gene in rye (Secale cereale L.). Euphytica 201, 43-52.

Stracke S., Schilling A.G., Forster J., Weiss C., Glass C., Miedaner T., Geiger H.H. 2003. Development of PCR-based markers linked to dominant genes for male-fertility restoration in Pampa CMS of rye (Secale cereale L.). Theor. Appl. Genet. 106, 1184-1190.

Van Ooijen J.W. 2004. MapQTL ${ }^{\circledR 5}$ Software for the mapping of quantitative trait loci in experimental populations. Wageningen, Netherlands, Kyazma B.V.

Van Ooijen J.W., Voorrips R.E. 2001. JoinMap® 3.0, Software for the calculation of genetic linkage maps. Wageningen, Netherlands, Plant Research International.

Wricke G., Wilde P., Wehling P., Gieselmann C. 1993. An isozyme marker for pollen fertility restoration to the Pampa cms system of rye (Secale cereale L.). Plant Breed 111, 290-294.

Żyto ozime, http://www.kws-zboza.pl/en/odmiany/wszystkie-odmiany/zboze/zyto-ozime.html, access: 31.03.2017. [in Polish]

Abstract. In this study, we aimed to apply a high-throughput genotyping method to map genes important for the restoration of male fertility in a hybrid cultivar of rye containing the Pampa sterilizing cytoplasm. The diversity arrays technology (DArT) was used to analyse 48 individuals of the F2 population obtained by crossing the male-sterile S305P line with a plant randomly chosen in the Gonello F1 cultivar. In addition to DArT markers, a set of previously published PCR-based markers was also used for genotyping. In total, more than 3300 markers were used in this study. A mapping analysis allowed a construction of seven linkage groups containing 763 markers covering a total distance of approximately $520 \mathrm{cM}$. Eighty molecular markers were applied to identify genomic regions important for the male fertility restoration. Their distribution indicated the presence of a major and minor restorer genes on chromosomes $4 R L$ and $1 R$, respectively. These results were consistent with previous reports on the genetic control of the male fertility in the CMS-Pampa. Moreover, new molecular markers located in chromosomal regions significantly associated with the restoration of male fertility were found as well, including PCR-based markers converted from the DArT markers.

This work was financially supported by Polish Ministry of Agriculture and Rural Development (project No. 20). 